Reprod. Nutr. Dévelop., 1983, 23 (3), 553-565.

\title{
A critical period in the onset of parturition in rats and uterine sensitivity to estradiol and progesterone
}

\author{
J. MARIE, Chantal LEGRAND, J.-P. MALTIER, R. SCHOLLER (*) \\ Laboratoire de Physiologie de la Reproduction, Université P. et $M$. Curie, \\ 4. Place Jussieu, 75230 Paris Cedex 05, France. \\ $\left({ }^{*}\right)$ Fondation de Recherche en Hormonologie, 94260 Fresnes, France.
}

\begin{abstract}
Summary. The purpose of this paper was to impair normal parturition in rats in order to measure tissue levels of progestins and estrogens and compare these results with those of normal parturition in rats. Abnormal parturition was obtained by injection of isotonic saline into the uterine lumen of pregnant rats at the end of pregnancy or by handling the uterus. After each of these treatments on day 21 of pregnancy, parturition was impaired in 70 to $98 \%$ of the rats. When the treatments were carried out earlier or later in pregnancy, there was little or no impairment. Our results indicate transient discrepancies in plasma and tissue levels of steroids $6 \mathrm{~h}$ after treatment on day 21:20 $\alpha$-HP concentrations increased in treated rats compared to controls (uteri : + $470 \% ; \mathrm{p}<0.01$; ovaries : + $89 \%$; $p<0.001)$; concomitantly, there was a sharp rise in $P$ concentrations in uteri $1+74 \%$ : $p<0.05)$ and ovaries $(+52 \% ; p<0.05)$. Inversely, uterine concentrations of $E_{2}$ decreased $6 \mathrm{~h}$ after treatment compared to controls $(-30 \% ; \mathrm{p}<0.05)$, although there was a transient rise of $E_{2}$ in the ovaries $(+30 \% ; p<0.05)$.

Twenty-four hours later, $E_{2}$ concentrations were always lower in the uteri $1-30 \%$; $p<0.01$ ). No change in $E_{1}$ levels was noted in the uteri or ovaries of either the control or treated rats. The physiological significance of these changes and their consequences on uterine reactivity at term have been discussed. The data demonstrate that day 21 was a critical period in the parturient activity of the rat uterus which appears to be primarily affected by uterine levels of $E_{2}$ between days 21 and 22 of pregnancy.
\end{abstract}

\section{Introduction.}

In pregnant rat, there is good evidence that a change in the ratio of progesterone to estrogen is implicated in uterine reactivity near term. Dukes et al. (1974) postulated that during the last $48 \mathrm{~h}$ of pregnancy, changes in preparation for parturition could be divided into two successive phases, the first involving luteolysis with a decrease in plasma and uterine concentrations of progesterone between days 19 and 23 of pregnancy (Hashimoto et al., 1968 ; Wiest, 1970 ; Egg et al., 1974; Ichikawa et al., 1974; Sanyal, 1978) and the second an estrogen-dependent phase beginning when the concentration of progesterone falls below a critical level and that of estrogens attains a critical threshold. Yoshinaga et al., (1969), Shaikh (1971), Waynforth et al., (1972) and Shaikh et al., (1977) showed that estrogen concentration in ovarian venous plasma rises 
sharply from day 21. Some works studying the relevance of these changes in steroid hormone concentrations to parturient activity of the uterus, have focused on the effect on the uterus of interactions between ovarian steroids and catecholamines (norepinephrine or epinephrine) (Maltier and Cavaillé, 1978 ; Maltier et al., 1980).

We have shown previously (Maltier and Cavaillé, 1975) that isotonic saline injection into the uterine lumen seriously impairs parturition when performed on day 21 post coitum. Handling the uterus at the same stage of pregnancy also results in abnormal delivery, indicating that day 21 of pregnancy is a critical period in the onset of parturition in rat (Maltier and Cavaillé, 1975). A change in the balance of uterine epinephrine and norepinephrine has been previously reported by Maltier and Cavaille (1975) in association with these abnormal deliveries. The impairment observed after both treatments was similar to that described after ovariectomy (delayed parturition, partial delivery or no delivery ; Csapo and Wiest, 1969), suggesting that some disorders in ovarian steroids might be implicated in abnormal parturition.

The aim of the present paper was to compare plasma and tissue levels of progesterone (P), $20 \alpha$-dihydroprogesterone $\left(20 \alpha\right.$-HP) and estrogens $\left(E_{1}\right.$ and $\left.E_{2}\right)$ in rats with normal and abnormal parturition. The changes in hormonal levels accompanying abnormal delivery seemed to make our experimental rats excellent models for studying the chronology and localization of some endocrine events occurring in pregnant rat near term.

\section{Material and methods.}

Animals and treatments. - Primiparous Sprague-Dawley rats were used. They were fed with commercial laboratory chow (UAR B03). Female rats in groups of five per cage were kept under constant temperature $\left(23^{\circ} \mathrm{C}\right)$ and a lighting schedule of $14 \mathrm{~h}$ of light and $10 \mathrm{~h}$ of dark. One male was put into each of the cages for one night. Fourteen days later, the pregnant rats were screened by palpation. Fertilization was assumed to have occurred between 2 and 6 a.m., and this time was taken as day 1 of pregnancy.

Group 1. - At 10 a.m. on day 19, 20, 21 or 22 of pregnancy, the females were laparotomized under ether anesthesia and gently injected through each uterine horn with $0.5 \mathrm{ml}$ of isotonic saline, according to the procedure of Maltier and Cavaillé, (1975). Immediately after injection, the uterine horns were replaced in the abdomen. Half the animals treated at $10 \mathrm{a} . \mathrm{m}$. on day 21 were sacrificed 6 , 24 or $48 \mathrm{~h}$ later for blood and organ collection; the remaining rats were used to control delivery.

Group 2. - At 10 a.m. on day 21, the uterus was exposed and handled but no saline was injected. The uterine horns were then immediately replaced in the abdomen. The animals were sacrificed $6 \mathrm{~h}$ later for blood and tissue collection or were used to check the timing and process of delivery.

Group 3. - At $10 \mathrm{a} . \mathrm{m}$. on day 21, the rats were anesthetized with ether and the abdomen opened without handling the uterus. All these rats were used to control hormonal levels and parturition. 
Group 4. - At 10 a.m. on day 21 of pregnancy, the rats were treated the same way as the females of group 1 and then immediately given s.c. either $3 \mu \mathrm{g}$ of estradiol dipropionate (Roussel-Uclaf) in $0.5 \mathrm{ml}$ of olive oil or the vehicle alone. All these rats were allowed to deliver spontaneously.

Group 5. - The females were left intact and used to control parturition. Those in all groups used for control of delivery were autopsied after 12 noon on day 23 to determine if parturition was complete or partial.

Enzyme assays. - The rats were killed by cervical dislocation and their ovaries immediately isolated and frozen in liquid nitrogen before enzyme assay. Ovarian tissues were analyzed biochemically for $\Delta 5-3 \beta$ and $20 \alpha$-hydroxysteroid dehydrogenase (OHSDH) by methods previously described by Wilcox and Wiest (1966) and Kuhn and Briley (1970) and then applied by Lacy et al., (1976).

$\triangle 5-3 \beta-O H S D H$. - The ovaries were homogenized in $1.5 \mathrm{ml}$ of $0.25 \mathrm{M}$ sucrose at $0{ }^{\circ} \mathrm{C}$. The homogenate was centrifuged for $30 \mathrm{~min}$ at $85000 \times \mathrm{g}$. The supernatant was taken for assay of $\Delta 5-3 \beta-\mathrm{OHSDH}$. The standard reaction mixture was glycine $\left(40 \mu\right.$ mol) $\mathrm{NaOH}$ buffer, $\mathrm{pH}$ 9.4, containing $\mathrm{NAD}^{+}$ $(0.3 \mu \mathrm{mol})$, nicotinamide $(10 \mu \mathrm{mol})$ and supernatant $(150 \mu \mathrm{l})$ in a final volume of $750 \mu \mathrm{l}$. The extinction change was measured in a spectrophotometer (Beckman DBT) at $340 \mathrm{m \mu}$ before and after the addition of $50 \mu \mathrm{l}$ of ethanolic pregnenolone $(0.1 \mathrm{ng} / \mathrm{ml})$. Rates were proportional to amounts of enzyme and dependent on added $\mathrm{NAD}^{+}$.

$20 \alpha-O H S D H$. - The ovaries were homogenized in Tris- $\mathrm{HCl}$ buffer $0.1 \mathrm{M}$, $\mathrm{pH} 7.4$ (30 $\mu$ l of buffer/mg of ovary), containing cysteine (1 mM), EDTA (1 mM) and nicotinamide $(10 \mathrm{mM})$. The homogenate was centrifuged for $30 \mathrm{~min}$ at $20000 \times \mathrm{g}$ and the supernatant was used for the assay of $20 \alpha-\mathrm{OHSDH}$. The standard reaction mixture was Tris- $\mathrm{HCl}$-cysteine buffer, $\mathrm{pH} 8, \mathrm{NADP}+(0.5 \mu$ mol) and supernatant $(200 \mu \mathrm{l})$ in a final volume of $750 \mu \mathrm{l}$. The extinction change was measured in a spectrophotometer (Beckman DBT) at $340 \mathrm{~m} \mu$ before and after the reaction was initiated with $50 \mu \mathrm{l}$ of ethanolic $20 \alpha-\mathrm{HP}(0.1 \mathrm{mg} / \mathrm{ml})$. Rates were dependent on enzyme and NADP+.

Steroid assays. - Steroid determinations were obtained by radioimmunological assays of uterine and plasma samples during the last 3 days of pregnancy in treated and control rats (groups 1,2 and 3). Blood was collected under ether anesthesia. Uterine blood was obtained at the cervical portion of the vein after ligation of its ovarian end. Peripheral blood was drawn from the aorta into a heparinized syringe. All blood samples were collected in heparinized flasks and then centrifuged at $1500 \times \mathrm{g}$ for $15 \mathrm{~min}$ at $0{ }^{\circ} \mathrm{C}$; the plasma was immediately processed for RIA. Ovaries and uteri were rapidly isolated, weighed and frozen in liquid nitrogen until steroid analysis. The procedures used in RIA were carried out according to methods described by Castanier and Scholler (1970), Florensa and Sommerville (1973) and Abraham (1974). [1,2,-(n)-3H] P (49 Ci/mmol ; Radiochemical Centre, Amersham, England); $\left[1,2,-(n)-{ }^{3} \mathrm{H}\right] 20 \alpha-\mathrm{HP}$ (40 Ci/mmol ; New England Nuclear $\mathrm{GmbH}$, West Germany) ; $\left[2,4,6,7-{ }^{3} \mathrm{H}\right] \mathrm{E}_{1}$ (55 Ci/mmol ; Radiochemical Centre, Amersham, England) and $[2,4,6,7-3 \mathrm{H}] \mathrm{E}_{2}$ (108 Ci/mmol ; Radiochemical Centre, Amersham, England) were purified by 
column chromatography before use. The $\mathrm{P}$ antiserum (anti-progesterone-11 $\alpha$ [succinyl] -bovine serum albumin), used at a final dilution of $1: 3000$, had no significant cross-reactivity with $20 \alpha$-HP $(1 \%), 5 \alpha$-pregnan-3,20-dione $(2.5 \%)$, $5 \beta$-pregnan-3,20-dione $(2 \%)$ or deoxycorticosterone $(3.5 \%)$. The $20 \alpha$-HP antiserum (anti-20 $\alpha$-hydroxy-4-pregnen-3-one-3 [0-carboxymethyl-oxime] -bovine serum albumin), a gift of Endocrine Sciences (Tarzana, California), was used at a final dilution of $1: 3000$; this antibody had a cross-reactivity of $10 \%$ with $20 \beta$ HP but no significant cross-reactivity $(<0.3 \%)$ with any of the other steroids. $E_{1}$ (or $E_{2}$ ) antiserum, obtained from rabbits after immunization with $E_{1}-17$ carboxymethyl-oxime-serum albumin conjugate, was used at a final dilution of $1: 30000$; this antiserum had a cross-reactivity of $4 \%$ with estriol and no significant cross-reactivity $(<0.1 \%)$ with cortisol, androgens or progestins. The standard curves of the assay ranged linearly between 0 and $600 \mathrm{pg}$ per assay tube for progestins and between 0 and $160 \mathrm{pg}$ per assay tube for estrogens.

We extracted duplicate samples twice with $4 \mathrm{ml}$ of diethyl ether (Merck; diethyl ether dried GR) ; about $1000 \mathrm{cpm}$ of radioactive steroids had been added to these for estimation of procedural loss.

Sample residues, dissolved in $100 \mu$ l of solvent, were applied to $0.6 \times 5-\mathrm{cm}$ Sephadex LH-20 columns with benzene-ethanol (85:15) as solvent for $E_{1}$ and $E_{2}$ and to $0.6 \times 17-\mathrm{cm}$ Sephadex LH-20 columns with benzene-methanol $(95: 5)$ as solvent for $\mathrm{P}$ and $20 \alpha-\mathrm{HP}$. Steroid recovery was determined in the extracts by scintillation spectrometry (Isocap 3000, Nuclear Chicago). Recovery (mean \pm SEM) was $89 \pm 3.2 \%$ for $P, 88 \pm 4.5 \%$ for $20 \alpha-H P, 84 \pm 7.3 \%$ for $E_{1}$ and $86 \pm 13.7 \%$ for $E_{2}$. The extracts for progestin determination were incubated for $30 \mathrm{~min}$ at $37^{\circ} \mathrm{C}$ with $\left.2500 \mathrm{cpm} \mathrm{[}{ }^{3} \mathrm{H}\right] \mathrm{P}$ or $\left[{ }^{3} \mathrm{H}\right] 20 \alpha-\mathrm{HP}$ and $\mathrm{P}$ or $20 \alpha-\mathrm{HP}$ antiserum. For estrogen determination, the extracts were incubated for $30 \mathrm{~min}$ at $37{ }^{\circ} \mathrm{C}$ with $4000 \mathrm{cpm}$ of radioactive steroid and $E_{1}$ or $E_{2}$ antiserum. Bound radioactive steroid was determined after removal of unbound steroid according to the procedure of Castanier and Scholler (1970).

Assay sensitivity was $0.2 \mathrm{ng} / \mathrm{ml}$ for $\mathrm{P}$ and $0.05 \mathrm{ng} / \mathrm{ml}$ for $20 \alpha-\mathrm{HP}, E_{1}$ and $E_{2}$. The intra-assay coefficient of variation was $6.7 \%$ for $P, 6.5 \%$ for $20 \alpha$-HP, $7 \%$ for $E_{1}$ and $E_{2}$. The interassay coefficient of variation was $11.6 \%$ for $P, 13.8 \%$ for $20 \alpha-H P$ and $14 \%$ for $E_{1}$ and $E_{2}$.

Statistical methods. - The results were analyzed statistically using Student's ttest. A difference was considered statistically significant when double-tailed $p$ was $<0.05$.

\section{Results.}

In control and untreated Sprague-Dawley rats (groups 3 and 5), parturition normally occurred between 12 noon on day 22 and 12 noon on day 23 of pregnancy (fig. 1). After injections of intra-uterine isotonic saline at $10 \mathrm{a} . \mathrm{m}$. on day 21 (fig. 1), $2 \%$ of the rats had completely normal delivery and $42 \%$ entirely suppressed delivery, the whole litter remaining in the uterus after 12 noon on day 23 and resulting in the death of the dam ; $49 \%$ of the rats had partial delivery, 


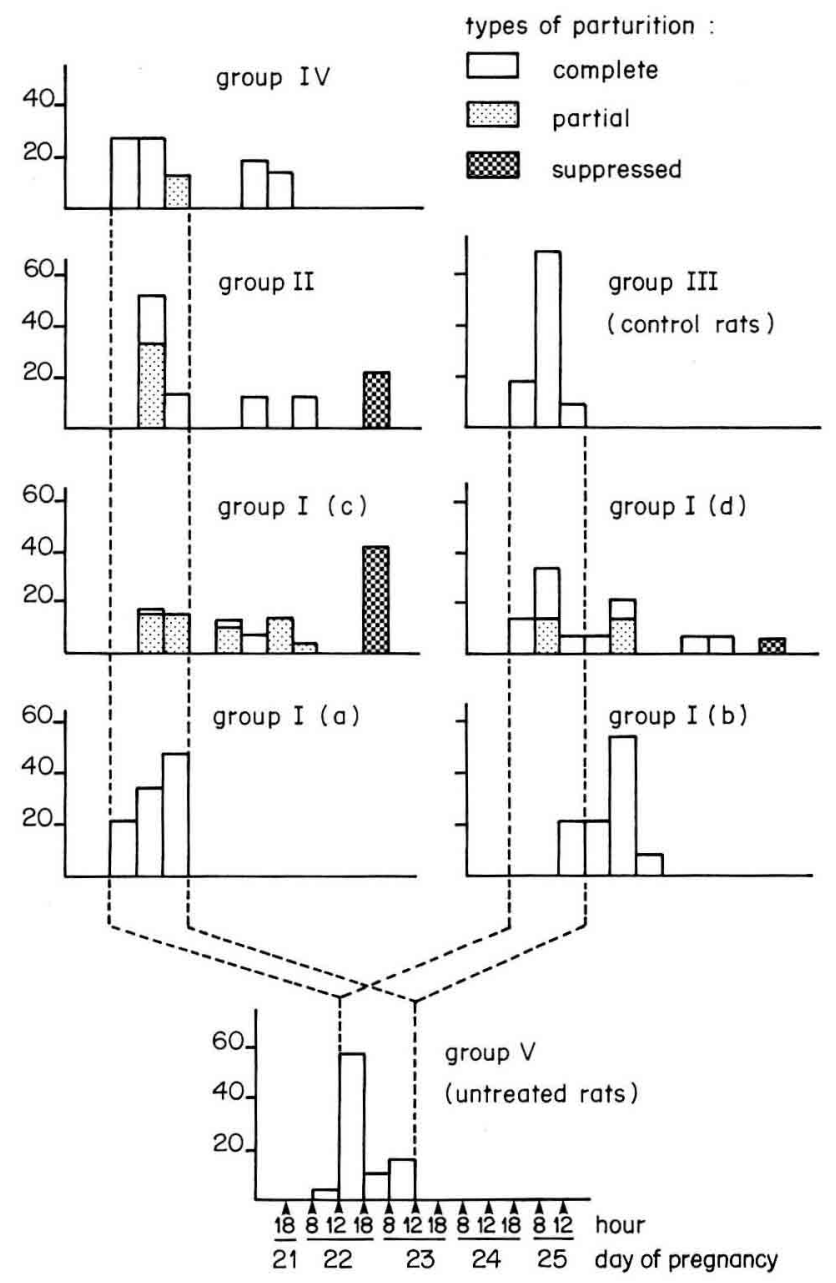

FIG. 1. - The timing and process of parturition in control and treated rats.

Group 1. Rats were treated with an intrauterine injection of saline at 10 a.m. on day 19 (a), day 20 (b), day 21 (c) or day 22 (d) of pregnancy. Group 2. Rats were laparotomized and their uterine horns exposed and handled at $10 \mathrm{a}$.m. on day 21. Group 3. Rats were laparotomized at 10 a.m. on day 21 without handling the uterus. Group 4. Rats were injected i.u. with isotonic saline at 10 a.m. on day 21 and received $3 \mu \mathrm{g}$ of estradiol dipropionate. Group 5. Untreated rats. Parturition normally occurred between 12 noon on day 22 and 12 noon on day 23 of pregnancy (dashed lines).

some fetuses remaining in the uterus after 12 noon on day 23. Parturition was complete but delayed in $7 \%$ of the rats. After laparotomy and handling of the uterus, we noted analogous, though less severe, consequences (fig. 1). The administration of estradiol dipropionate at 10 a.m. on day 21 immediately after isotonic saline resulted in a high proportion of complete deliveries ( $88 \%$ ), partial deliveries (12\%) occurring at the normal time (fig. 1). Moreover, in this group of animals, we never observed suppressed parturition. Ether anesthesia and 
laparotomy without handling the uterine horns had no effect on parturition (fig. 1). After injection of intrauterine isotonic saline at 10 a.m. on day 19, all deliveries were normal ; after injection at 10 a.m. on day 20 or 22 , we noted less severe consequences than after injection at 10 a.m. on day 21 (fig. 1).

$P$ concentrations (fig. 2). - At 4 p.m. on day 21, i.e. $6 \mathrm{~h}$ after saline injection, uterine $P$ concentration increased compared to control rats $1+74 \%$; $p<0.05)$. The same results were noted after handling the uterus since the $P$ level was $83.2 \pm 16.9 \mathrm{ng} / \mathrm{g}$ with no significant difference between either group of treated rats. These changes appeared concomitantly with a similar increase of

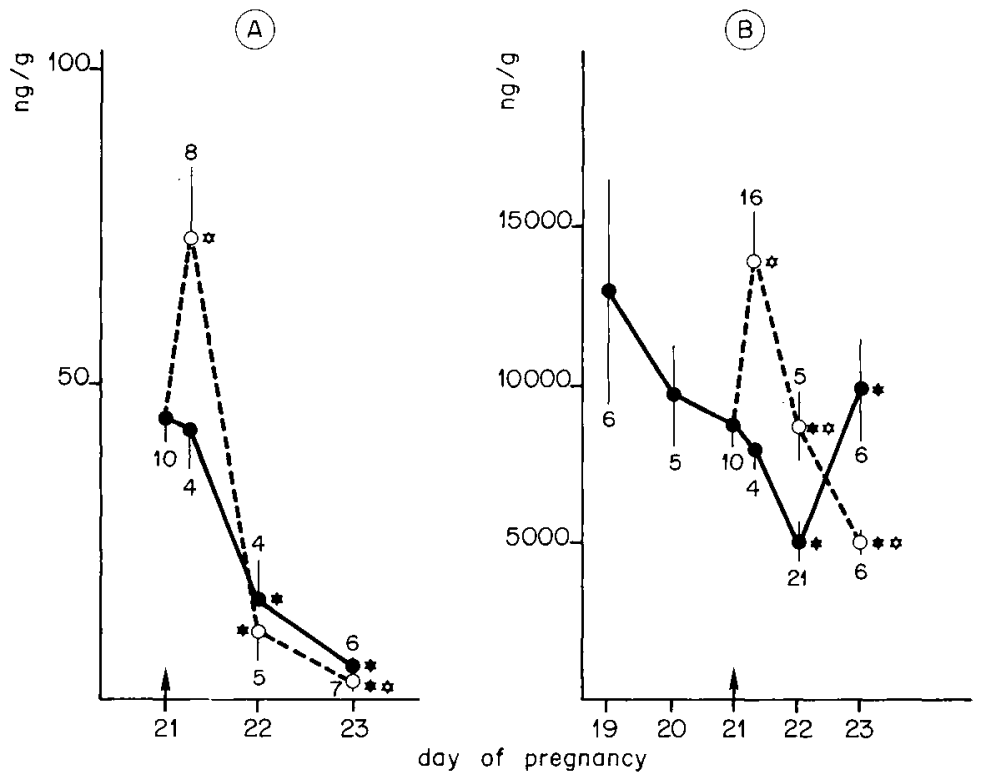

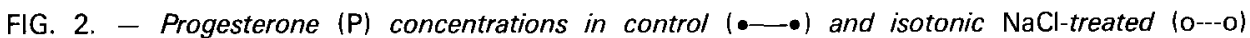
rats. The means \pm SEM are indicated. The ciphers on the figure are the numbers of animals.

A : uterus, B : ovaries.

is : significantly different from values in control rats $(p<0.05)$.

$\star$ : significantly different from values at previous stage of pregnancy $(p<0.05)$.

- : The arrow indicate the time of injection.

ovarian $\mathrm{P}$ concentrations after saline injection $(+52 \% ; \mathrm{p}<0.05)$ or handling the uterus (13 $253 \pm 2418 \mathrm{ng} / \mathrm{g}$ ). This elevation was not correlated with a change in ovarian $\Delta_{5}-3 \beta-\mathrm{OHSDH}$ (table 1). Within $24-48 \mathrm{~h}$ after treatment, i.e. at 10 a.m. on day 22 or 23 of pregnancy, uterine $P$ concentrations decreased to within a normal or subnormal range; on day 23 , a decrease in ovarian $P$ concentration was noted $(-47 \% ; \mathrm{p}<0.05)$, associated with a decline in $\Delta_{5^{-}}$ $3 \beta$-OHSDH activity (table 1 ). In contrast, ovarian $\mathrm{P}$ concentrations of normal control rats rose near term $(+96 \% ; \mathrm{p}<0.05)$ concomitantly with higher ovarian $\Delta_{5}-3 \beta-\mathrm{OHSDH}$ activity (table 1 ). 
TABLE 1

$\Delta_{5} 3 \beta$ and $20 \alpha-\mathrm{OHSDH}$ activities in control and saline-treated rats (means \pm SEM)

\begin{tabular}{|c|c|c|c|c|c|c|c|}
\hline \multirow{3}{*}{$\begin{array}{c}\begin{array}{c}\text { Day of } \\
\text { pregnancy }\end{array} \\
19\end{array}$} & \multicolumn{4}{|c|}{$\Delta_{5}-3 \beta-\mathrm{OHSDH}(\mathrm{mU} / \mathrm{mg}$ ovary $)$} & \multicolumn{3}{|c|}{$20 \alpha-\mathrm{OHSDH}(\mathrm{mU} / \mathrm{mg}$ ovary) } \\
\hline & \multicolumn{2}{|c|}{ Control rats } & \multicolumn{2}{|l|}{ Treated rats } & Control rats & \multicolumn{2}{|l|}{ Treated rats } \\
\hline & $0.62 \pm 0.06$ & (8) & - & & $0.93 \pm 0.09$ & - & \\
\hline 20 & $0.57 \pm 0.04$ & (5) & - & & $1.67 \pm 0.12 \star(6)$ & - & \\
\hline 21 & $0.74 \pm 0.10$ & (9) & $0.91 \pm 0.11$ & (6) & $2.10 \pm 0.36$ & $1.47 \pm 0.09$ & (9) \\
\hline 22 & $1.00 \pm 0.15$ & (9) & $0.86 \pm 0.18$ & (6) & $1.07 \pm 0.11 \star(14)$ & $2.28 \pm 0.35 \star$ & (6) \\
\hline 23 & $1.89 \pm 0.27 \star$ & (8) & $0.36 \pm 0.04 \star$ & (4) & $1.98 \pm 0.25 \star(8)$ & $2.58 \pm 0.09$ & (5) \\
\hline
\end{tabular}

The number of animals is shown in parentheses.

is : significantly different from values in control rats $(p<0.05)$.

$\star$ : significantly different from values at previous stage of pregnancy $(p<0.05)$.

20 $\alpha$-HP concentrations (fig. 3). Six hours after i.u. isotonic saline, uterine $20 \alpha$-HP concentrations increased sharply $(+470 \% ; p<0.01)$; in this group, the hormone levels were closely similar to those measured after the uterus was handled $(26.7 \pm 12.3 \mathrm{ng} / \mathrm{g})$. Concomitantly, we noted a rapid increase in $20 \alpha-$ HP concentrations in ovaries $(+89 \% ; p<0.001)$ of saline-treated rats as well as in rats whose uterus had been handled $(6508 \pm 441 \mathrm{ng} / \mathrm{g}$ ).

As shown in table 1, this ovarian increase in $20 \alpha$-HP concentrations was not a result of higher $20 \alpha-\mathrm{OHSDH}$ activity. Later, i.e. at 10 a.m. on day 23 , while ovarian $20 \alpha-\mathrm{HP}$ concentrations decreased sharply compared to control rats $(-79 \% ; p<0.05)$, hormone levels in the uterus were within the normal range of the control rats.

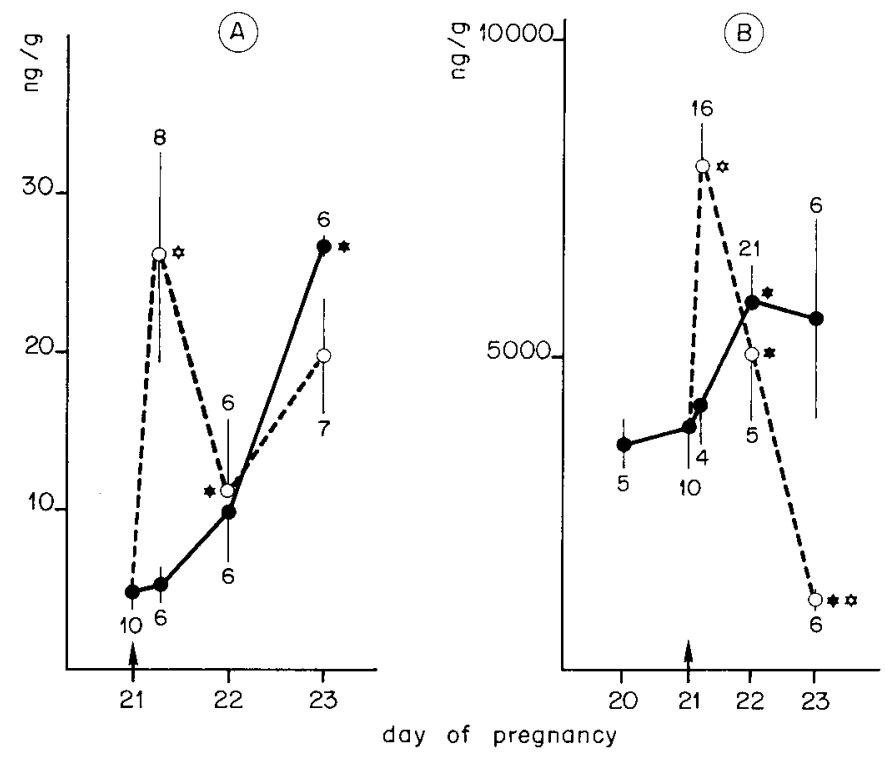

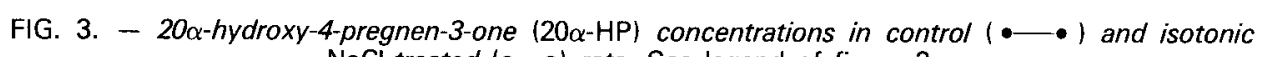
$\mathrm{NaCl}$-treated (0---o) rats. See legend of figure 2. 
Estrogen concentrations. - Figure 4 shows changes in mean $E_{2}$ concentrations in the uteri, plasma and ovaries of control and treated pregnant rats. Within the last 2 days of pregnancy, the concentrations of $E_{2}$ in control rats increased in the uteri and plasma. Between days 21 and 22, this increase was only significant in uteri $(+50 \% ; p<0.01)$; between days 22 and 23 , it was $+204 \%(p<0.01)$ in the uterus and $+591 \% \cdot(p<0.001)$ in the peripheral plasma.
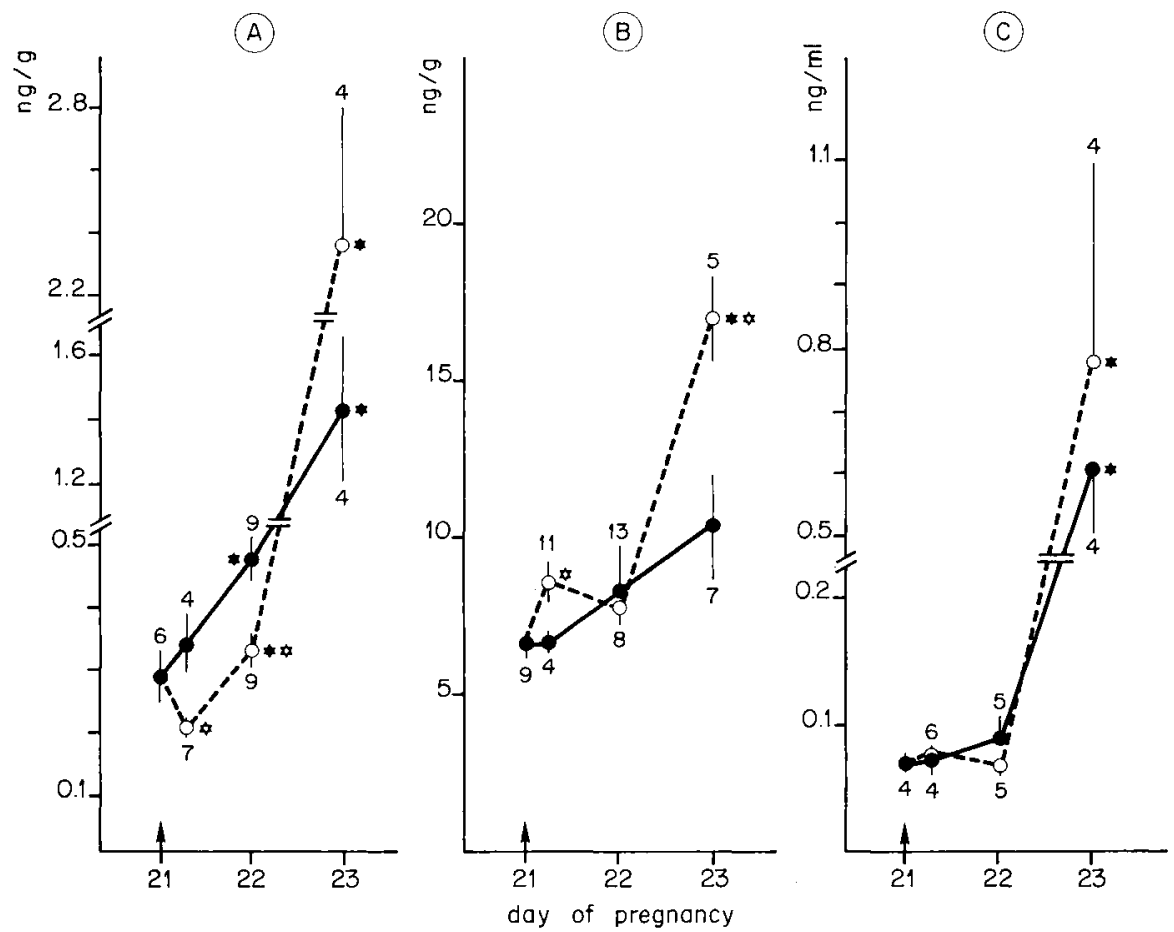

FIG. 4. - Estradiol $\left(\mathrm{E}_{2}\right)$ concentrations in control $(\bullet-\bullet)$ and isotonic $\mathrm{NaCl}$-treated (0---o) rats. See legend of figure 2 .

A : uterus, B : ovaries, C : peripheral plasma.

Six hours after i.u. isotonic saline injection, uterine concentrations of $E_{2}$ were significantly lower $(-30 \% ; p<0.05)$, although at this stage ovarian concentrations increased $(+30 \% ; \mathrm{p}<0.05)$ and plasma levels were not different. Thus, the ut:pl ratio decreased $(-34 \% ; p<0.05)$ within the next $6 \mathrm{~h}$ after treatment. Twenty-four hours later, i.e. at $10 \mathrm{a} . \mathrm{m}$. on day 22, the levels of $E_{2}$ were always low in the uterine tissues of treated rats $(-30 \% ; p<0.01)$. At 10 a.m. on day 23 , i.e. $48 \mathrm{~h}$ after treatment, the uterine levels of $E_{2}$ were within the range of the controls. Since plasma levels of $E_{2}$ were also similar in treated and untreated rats, the ut:pl ratio was not different in either group of animals at term. 
As shown in figure 5 , the concentrations of $E_{1}$ in uteri or ovaries of treated animals remained within the range of control preparturient rats. Moreover, on days 22 and 23 of pregnancy, the levels of $E_{2}$ and $E_{1}$ in uterine venous blood were always similar to the values of peripheral plasma (table 2). In animals from which uterine tissues and peripheral plasma had been simultaneously sampled, we noted a highly positive correlation ( $n=20, r=0.822 ; p<0.001$ ) among $E_{2}$ levels in both compartments.
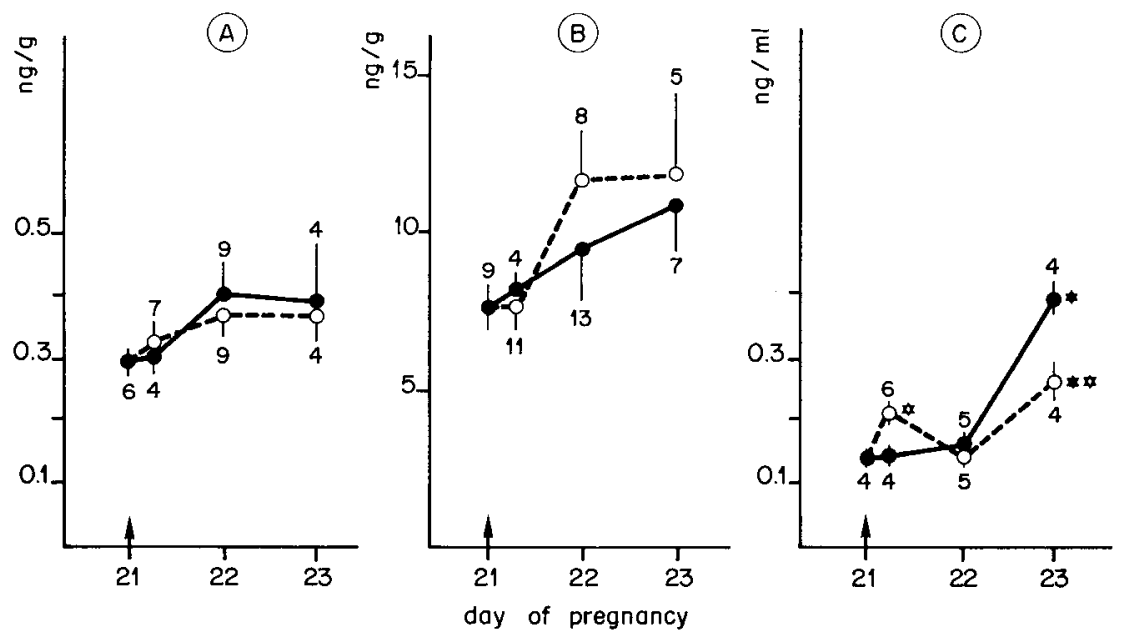

FIG. 5. - Estrone $\left(E_{1}\right)$ concentrations in control $\left.\bullet \longrightarrow\right)$ and isotonic $\mathrm{NaCl}-$ treated $(0---0)$ rats. See legend of figure 2 .

A : uterus, B : ovaries, C : peripheral plasma.

TABLE 2

Estradiol $\left(E_{2}\right)$ and estrone $\left(E_{1}\right)$ concentrations in uterine venous plasma of control and saline-treated rats (means \pm SEM)

\begin{tabular}{|c|c|c|c|c|c|c|}
\hline \multirow[t]{2}{*}{$\begin{array}{c}\text { Day of } \\
\text { pregnancy }\end{array}$} & \multicolumn{4}{|c|}{$\mathrm{E}_{2}(\mathrm{pg} / \mathrm{ml})$} & \multicolumn{2}{|c|}{$E_{1}(p g / m l)$} \\
\hline & Control rat & & Treated rat & & Control rats & Treated rats \\
\hline $\begin{array}{l}21 \\
22 \\
23\end{array}$ & 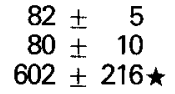 & $\begin{array}{l}(4) \\
(6) \\
(4)\end{array}$ & 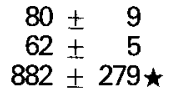 & $\begin{array}{l}\text { (7) } \\
\text { (4) } \\
(5)\end{array}$ & $\begin{array}{l}179 \pm 15(5) \\
161 \pm 30(6) \\
352 \pm 74(4)\end{array}$ & $\begin{array}{l}220 \pm 17(7) \\
152 \pm 21(4) \\
246 \pm 42(5)\end{array}$ \\
\hline
\end{tabular}

The number of animals is shown in parentheses.

$\star$ : significantly different from values at previous stage of pregnancy.

\section{Discussion.}

When performed on day 21 of pregnancy, injection of isotonic saline into the uterus of pregnant rat or only handling the uterus seriously impaired parturition; when the rats were treated earlier or later in pregnancy, there was 
little or no impairment. The impairment could be due to a failure in uterine contractility related to a change in the epinephrine-norepinephrine balance in the uterus (Maltier and Cavaillé, 1975). Therefore, the present findings clearly show that other hormonal discrepancies related to plasma and tissue steroid levels might also be implicated in saline-induced impairment of parturition. After both treatments, a transient increase in the uterine concentration of $P$ was noted. This would reflect a rise in plasma $P$ originating from the adrenals (surgical stress : Yoshinaga et al., 1967 ; Fajer et al., 1971) or from increased secretion of ovarian P (Pepe and Rothchild, 1973) since Legrand et al. (1979) showed that uterine $P$ concentrations mostly depend on changes in circulating $P$ levels. The transient increase of $\mathrm{P}$ and $20 \alpha-\mathrm{HP}$ in the ovaries suggests that the synthesis of both progestins was stimulated. Careful analysis of the changes in ovarian $20 \alpha-$ $\mathrm{OHSDH}$ or $\Delta_{5}-3 \beta-\mathrm{OHSDH}$ activities in, both control and saline-treated rats did not show any clear correlation between the concentrations of progestin in ovaries and enzymatic activity. This was also pointed out by Lacy et al. (1976) who consider that the biochemical method validated in vitro by Wilcox and Wiest (1966) and Kuhn and Briley (1970) does not " accurately reflect the in vivo activity of the enzyme " since other factors such as substrate or cofactor availability may regulate hormonal synthesis in vivo. Moreover, we have no rational explanation for the concomitant increase of $P$ and $20 \alpha-H P$ in the ovary of saline-treated rat, unless puncture or handling the uterus, a severe aggression on the fetus (Legrand and Maltier, 1981a), could induce the release of a fetoplacental luteotrophic substance, shown to stimulate the luteal function of midpregnant rat and induce a characteristic parallel rise in both gestagens (Sin et al., 1971). A change in the endometrial secretory $P G E / P G F_{2 \alpha}$ ratio, however, cannot be excluded.

The elevation of the uterine $\mathrm{P}$ level was transient ; within 24-48 h after both treatments, uterine $\mathrm{P}$ concentrations decreased to within a normal or subnormal range. Therefore, it cannot be considered that a " progesterone block " (Csapo, 1969) at term accounts for abnormal delivery.

In spite of a highly positive correlation among circulating $E_{2}$ levels and $E_{2}$ concentrations in the uteri, the decline in $E_{2}$ observed in uterine tissues $6 \mathrm{~h}$ after i.u. isotonic saline injection does not result from a clearance of $E_{2}$ in peripheral plasma. The diminution of the uterine concentrations of $E_{2}$ may be a local effect of the transient increase in $P$ levels. This concept agrees with previous evidence reported in rats (Resko et al., 1976) and rabbits (Batra et al., 1978), demonstrating that progesterone administration suppresses the accumulation of $E_{2}$ by uterine tissues, presumably by reducing the levels of $E_{2}$ receptors. According to the work of Wahawisan and Gorell (1980), this effect could also result from an inhibition of uterine $17 \beta-O H S D H$ that interconverts $E_{2}$ and $E_{1}$ in the rat uterus, favoring $E_{2}$ production. In our experiments, such an hypothesis seems unwarranted since uterine levels of $E_{1}$ were unchanged. Later, within 24$48 \mathrm{~h}$ after i.u. isotonic saline injection, changes in uterine concentrations of $E_{2}$ reflected those in peripheral plasma. Moreover, our results, demonstrating the similarity of $E_{1}$ and $E_{2}$ levels in uterine venous blood and peripheral plasma, indicate that estrogens do not originate from the placentae ; this is in agreement 
with previous data obtained in vitro by Sybulski (1970) and Townsend and Ryan (1970).

As shown by the present work, the most important changes in response to surgical treatment were seen in uterine concentrations of both progestins and estrogens within 6-24 h. When complete or partial parturition was delayed, this delay varied between 6 and $24 \mathrm{~h}$. Thus, when the chronology of the normal sequence of changes in $P$ and $E_{2}$ occurring on day 21 was delayed, we noted a similar delay in the timing of delivery.

When treatment was applied earlier on day 20 , the uterine $P / E_{2}$ ratio returned to normal on day 21 and, consequently, all the deliveries were complete. Our experimental data demonstrate that an adequate level of uterine $E_{2}$ is of major importance at this stage of pregnancy. Thus, a single injection of $E_{2}$-dipropionate, presumed to enhance plasma and uterine levels of $E_{2}$, resulted in $88 \%$ of complete delivery when given on day 21 simultaneously with i.u. isotonic saline injection. Moreover, in these conditions we never observed suppressed parturition. All these observations confirm the hypothesis of Catala and Deis (1973) and Dukes et al. (1974) that day 21 is a critical period in the onset of parturition in rats. We suggest that this stage of pregnancy is the time when the sequence of hormonal events leading to normal parturient activity in the rat uterus is organized.

The transient changes in uterine concentrations of both $P$ and $E_{2}$ noted immediately after i.u. isotonic saline or handling of the uterus were also followed by a modification in the uterine balance between epinephrine and norepinephrine (Maltier and Cavaillé, 1975). Thus, the chronology of these hormonal events suggests that the changes in catecholamine concentrations in the preparturient uterus of rat could be a consequence of changes in the $P$ and/or $E_{2}$ levels. This is in agreement with previous data which show that steroid hormones may regulate the uterine levels of catecholamines in the pregnant rat at term (Maltier and Cavaillé, 1978 ; Maltier et al., 1980).

Thus, subsequent changes in the adrenergic reactivity of the uterus may account for the partially delayed or suppressed delivery noted in our experimental rats and could explain the impairment of the electrical activity found in the myometrium of saline-treated rats (Legrand and Maltier, $1981 \mathrm{~b}$ ).

Reçu en octobre 1982.

Accepté en décembre 1982.

Acknowledgements. - This work was supported by an INSERM grant (ATP 75-79-107). We thank Dr. R. Scholler, Director of « Fondation de Recherche en Hormonologie " (Fresnes) which partially defrayed the expenses of this investigation.

Résumé. Existence d'une période critique dans la sensibilité utérine à l'cestradiol et à la progestérone au moment de la parturition chez la Ratte.

Chez la ratte, une injection intra-utérine de $0,5 \mathrm{ml}$ de chlorure de sodium isotonique ou la manipulation de l'utérus pratiquée au $21^{\circledR}$ jour, $10 \mathrm{~h}$ de la gestation provoque $70 \%$ à 
$98 \%$ de parturitions anormales. Les deux traitements sont immédiatement suivis d'une augmentation transitoire des concentrations de progestérone dans l'ovaire $1+52 \%$, $P<0,05)$ et l'utérus $(+74 \%, P<0,05)$. II en est de même pour les concentrations de $20 \alpha$-dihydroprogestérone dans l'ovaire $(+89 \%, P<0,001)$ et l'utérus $(+470 \%$, $P<0,01)$. A l'inverse, sous l'effet du traitement, les concentrations utérines de l'œstradiol diminuent brutalement $(-30 \%, \mathrm{P}<0,05)$ malgré une élévation transitoire du niveau ovarien de l'hormone $(+30 \%, P<0,05)$. Au $22^{\mathrm{e}}$ jour, $12 \mathrm{~h}$ de gestation, les concentrations utérines de l'œstradiol restent plus faibles que celles notées chez les rattes contrôles $(-30 \%, P<0,01)$. La signification physiologique de ces changements hormonaux et leurs conséquences sur la réactivité de l'utérus préparturient sont discutées. En outre, nos résultats démontrent que le $21^{\mathrm{e}}$ jour de la gestation chez la ratte est la période critique pour l'initiation de la parturition puisque les mêmes traitements appliqués avant ou après cette date n'entraînent que peu ou pas de perturbations.

\section{References}

ABRAHAM G. E., 1974. Radioimmunoassay of steroids in biological materials. Acta endocrinol. Kbh., Suppl. 183, 1-42.

BATRA S., SJÖBERG N. O., THORBERT G., 1978. Estrogen and progesterone interactions in the rabbit uterus in vivo after steroid administration. Endocrinology, 102, 268-272.

CASTANIER M., SCHOLLER R., 1970. Dosage radioimmunologique de I'œstrone et de l'œstradiol-17 $\beta$ plasmatiques. C.R. Acad. Sci. Paris, Sér. D, 271, 1787-1789.

CATALA S., DEIS R. P., 1973. Effect of oestrogen upon parturition, maternal behaviour and lactation in ovariectomized pregnant rats. J. Endocrinol., 56, 219-225.

CSAPO A., 1969. The four direct regulatory factors of myometrial function, 13-42. In G.E.W. WOLSTENHOLME, J. KNIGHT, Progesterone: its regulatory effect on the myometrium, Ciba Foundation Study Group No. 34. Churchill, London.

CSAPO A. I., WIEST W. G., 1969. An examination of the quantative relationships between progesterone and the maintenance of pregnancy. Endocrinology, 85, 735-746.

DUKES M., CHESTER R., ATKINSON P., 1974. Effects of oestradiol and prostaglandin F2 $\alpha$ on the timing of parturition in the rat. J. Reprod. Fert., 38, 325-334.

EGG D., ZAMBELIS N., LOEWIT K., 1974. Progesterone in peripheral plasma and tissues during pregnancy in the rat. Exp. Path., 9, 307-310.

FAJER A. B., HOLZBAUER M., NEWPORT H. M., 1971. The contribution of the adrenal gland to the total amount of progesterone produced in the female rat. J. Physiol. (London), 214, 115-126.

FLORENSA E., SOMMERVILLE I. F., 1973. Radioimmunoassay of plasma $20 \alpha$-dihydroprogesterone. Steroids, 22, 451-465.

HASHIMOTO I., HENRICKS D. M., ANDERSON L. L., MELAMPY R. M., 1968. Progesterone and pregn-4-en-20 $\alpha$-ol-3-one in ovarian venous blood during various reproductive states in the rat. Endocrinology, 82, 333-341.

ICHIKAWA S., SAWADA J., NAKAMURA Y., MORIOKA H., 1974. Ovarian secretion of pregnane compounds during the estrous cycle and pregnancy in rats. Endocrinology, 94, 1615-1620.

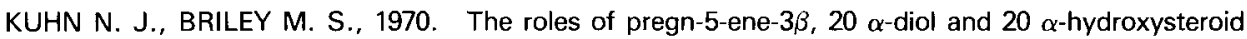
dehydrogenase in the control of progesterone synthesis preceding parturition and lactogenesis in the rat. J. Biochem. 117, 193-201.

LACY L. R., KNUDSON M. M., WILLIAMS J. J., RICHARDS J. S., MIDGLEY A. R., 1976. Progesterone metabolism by the ovary of the pregnant rat : discrepancies in the catabolic regulation model. Endocrinology, 99, 929-934.

LEGRAND C., MALTIER J. P., 1981 a. Foetal and maternal plasma adrenaline and noradrenaline concentrations in the late pregnant rat : effects of intra-uterine isotonic saline or uterine handling. Acta endocrinol., 96, 541-545. 
LEGRAND C., MALTIER J. P., 1981 b. Activité électrique de l'utérus chez la rate préparturiente, 61-68. In BOURY-HEYLER C., MAULEON P., ROCHET Y.,Utérus et fécondité, Masson, Paris.

LEGRAND C., SYNGUELAKIS M., EMMERICH A., ROBEL P., 1979. Relationships among placental, uterine and circulating concentrations of progesterone and fetal survival in the ovariectomized pregnant rat. Endocrinology, 105, 58-63.

MALTIER J. P., CAVAILLE F., 1975. Effects of injections of monoamine oxidase inhibitor or saline into the uterus in late pregnancy on uterine catecholamine levels related to abnormal parturition in rats. J. Endocrinol, 67, 371-383.

MALTIER J. P., CAVAILLÉ F., 1978. Effects of ovariectomy, progesterone and oestrogen on uterine catecholamine concentrations in relation to parturition in rats. J. Endocrinol., 76 , 93-100.

MALTIER J. P., LEGRAND C., PALERMO G., MARIE J., 1980. Evolutions comparées des concentrations des catécholamines et des progestines dans l'utérus de ratte en fin de gestation. Ann. Endocrinol., 41, 33.

PEPE G. J., ROTHCHILD I., 1973. Metabolic clearance rate of progesterone: comparison between ovariectomized, pregnant, pseudopregnant and deciduoma-bearing pseudopregnant rats. Endocrinology, 93, 1200-1205.

RESKO J. A., BOLING J. L., BRENNER R. M., BLANDAU R. J., 1976. Sex steroids in reproductive tract tissues: regulation of estradiol concentrations by progesterone. Biol. Reprod., 15, 153-157.

SANYAL M. K., 1978. Secretion of progesterone during gestation in the rat. J. Endocrinol., 79 , 179-190.

SHAIKH A. A., 1971. Estrone and estradiol levels in the ovarian venous blood from rats during the estrous cycle and pregnancy. Biol. Reprod., 5, 297-307.

SHAIKH A. A., NAQVI R. H., SAKSENA S., 1977. Prostaglandins $E$ and $F$ in uterine venous plasma in relation to peripheral plasma levels of progesterone in the rat throughout pregnancy and parturition. Prostaglandins, 13, 311-320.

SIN J. G., ETO T., HASHIMOTO I., SUZUKI Y., 1971. Participation of the pregnant uterus upon the gestagen secretion during mid-pregnancy in the rat. Endocrinol. jap., 18, 495-500.

SYBULSKI S., 1970. Testosterone metabolism by homogenates of human and rat placenta. Experientia, 26, 539-542.

TOWNSEND L., RYAN K. J., 1970. In vitro metabolism of pregnenolone- $7 \alpha^{-}{ }^{3} \mathrm{H}$, progesterone-4- ${ }^{14} \mathrm{C}$ and androstenedione-4- ${ }^{14} \mathrm{C}$ by rat placental tissue. Endocrinology, 87, 151-155.

WAHAWISAN R., GORELL T. A., 1980. Steroidal control of rat uterine 17 $\beta$-hydroxysteroid dehydrogenase activity. Steroids, 36, 115-129.

WAYNFORTH H. B., POPE G. S., HOSKING Z. D., 1972. Secretion rates of oestrogens into the ovarian venous blood of pregnant rats. J. Reprod. Fert., 28, 191-196.

WIEST W. G., 1970. Progesterone and $20 \alpha$-hydroxy-pregn-4-en-3-one in plasma, ovaries and uteri during pregnancy in the rat. Endocrinology, 87, 43-48.

WILCOX R. B., WIEST W. G., 1966. Further studies of rat ovarian $20 \alpha$-hydroxysteroid dehydrogenase. Steroids, 7, 395-413.

YOSHINAGA K., GRIEVES S. A., SHORT R. V., 1967. Steroidogenic effects of luteinizing hormone and prolactin on the rat ovary in vivo. J. Endocrinol., 38, 423-430.

YOSHINAGA K., HAWKINS R. A., STOCKER J. F., 1969. Estrogen secretion by the rat ovary in vivo during the estrous cycle and pregnancy. Endocrinology, 85, 103-112. 